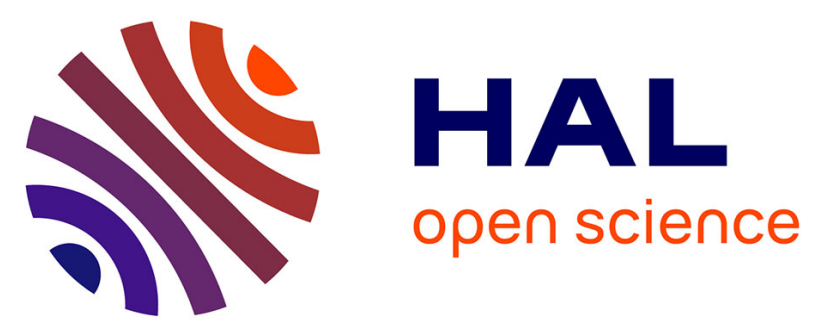

\title{
Equity Crowdfunding: Quality Signals for Online-Platform Projects and Supporters' Motivations
}

Benjamin Buerger, Andreas Mladenow, Niina Maarit Novak, Christine Strauss

\section{To cite this version:}

Benjamin Buerger, Andreas Mladenow, Niina Maarit Novak, Christine Strauss. Equity Crowdfunding: Quality Signals for Online-Platform Projects and Supporters' Motivations. 12th International Conference on Research and Practical Issues of Enterprise Information Systems (CONFENIS), Sep 2018, Poznan, Poland. pp.109-119, 10.1007/978-3-319-99040-8_9 . hal-01963058

\section{HAL Id: hal-01963058 \\ https://hal.inria.fr/hal-01963058}

Submitted on 21 Dec 2018

HAL is a multi-disciplinary open access archive for the deposit and dissemination of scientific research documents, whether they are published or not. The documents may come from teaching and research institutions in France or abroad, or from public or private research centers.
L'archive ouverte pluridisciplinaire HAL, est destinée au dépôt et à la diffusion de documents scientifiques de niveau recherche, publiés ou non, émanant des établissements d'enseignement et de recherche français ou étrangers, des laboratoires publics ou privés.

\section{(c)(1)}

Distributed under a Creative Commons Attribution| 4.0 International License 


\title{
Equity Crowdfunding: Quality Signals for Online- Platform Projects and Supporters' Motivations
}

\author{
Benjamin Buerger ${ }^{1}$, Andreas Mladenow ${ }^{1, *}$, Niina Maarit Novak ${ }^{2}$, Christine Strauss $^{1}$ \\ ${ }^{1}$ University of Vienna, Department of e-Business, Faculty of Business, Economics \\ and Statistics, Oskar-Morgenstern-Platz 1 A-1090 Vienna, Austria, \\ \{buergerb42, andreas.mladenow, christine.strauss\}@univie.ac.at \\ ${ }^{2}$ Vienna University of Technology, Institute of Information Systems Engineering, \\ Favoritenstraße 9-11, 1040 Vienna, Austria \\ niina.novak@tuwien.ac.at
}

\begin{abstract}
The paper assesses and evaluates quality signals for online platform projects and motivations for equity crowdfunding which might increase a potential supporter's propensity to commit his financial resources. Based on a literature analysis a number of motives that may have an effect on the investment decision and other non-motivational dimensions are taken into account as they might convey information about the underlying and often not directly observable qualitative characteristics of the business.
\end{abstract}

Keywords: Equity Crowdfunding, Supporters Motivations, Decision Support Systems, Collaboration, Social Interaction, HCI

\section{Introduction}

Equity crowdfunding describes a phenomenon that allows crowdsourcers to allocate funds by drawing on financial contributions from a distributed audience of supporters in exchange of equity or equity-like shares of the business [5]. In this regard, this paper looks into characteristics which might increase a potential investor's propensity to commit his financial resources with the focus on start-ups. This question is of practical importance as a broad support from the crowd is the crucial ingredient to make crowdfunding a serious alternative for allocating financial resources. After a literature review on crowdfunding, it seems reasonable to develop the categories contextual traits (quality signals) and supporters' motivations [11,21]. Contextual traits are supposed to enhance a funder's trust in both, the founder and the potential of the startups underlying characteristics by providing different signs of quality [21]. These traits stand beside and independently of the motivational dimensions and are considered to be a prerequisite for participation. In addition, four motivational categories are identified based on findings by Gerber and Hui [11]. In the next chapter, the motivational and contextual traits are discussed. Referring to Ordanini et al. we assume the possibility of a coexistence of these traits in a funder, but that the impact of each dimension might differ among individuals, initiatives and the crowdfunding form [21]. 


\section{Motivations of Supporters and Contextual Traits}

Considering recent literature covering equity crowdfunding, we suggest two categories for startup projects which might have a positive impact on the propensity to invest as depicted in Table 1.

Table 1. Motivations of supporters and contextual traits

\begin{tabular}{|c|c|c|}
\hline Category & $\begin{array}{l}\text { Motivational or } \\
\text { Contextual Traits }\end{array}$ & $\begin{array}{l}\text { Positive Impact on the Propensity to In- } \\
\text { vest }\end{array}$ \\
\hline $\begin{array}{l}\text { Quality Signals for } \\
\text { Equity Crowd- } \\
\text { funding Projects }\end{array}$ & Contextual Traits & $\begin{array}{l}\text { - Project Status } \\
\text { - Founder's Competence } \\
\text { - Frequent Interaction } \\
\text { - Community Effects } \\
\text { - Planning }\end{array}$ \\
\hline \multirow{4}{*}{$\begin{array}{l}\text { Motivations of } \\
\text { Supporters }\end{array}$} & Collect Rewards & $\begin{array}{l}\text { - Selfish Reciprocity } \\
\text { - Monetary Return } \\
\text { - Product Benefit } \\
\text { - Curiosity } \\
\text { - Hedonism }\end{array}$ \\
\hline & Support a Venture & $\begin{array}{l}\text { - Social Utility } \\
\text { - Innovativeness }\end{array}$ \\
\hline & Help Others & $\begin{array}{l}\text { - Sense of Identification with Founder } \\
\text { - Favorable Reciprocity } \\
\text { - Altruism }\end{array}$ \\
\hline & $\begin{array}{l}\text { Be Part of a Com- } \\
\text { munity }\end{array}$ & $\begin{array}{l}\text { - Social Identification } \\
\text { - Social Recognition }\end{array}$ \\
\hline
\end{tabular}

\subsection{Quality Signals}

Several quality signals are likely to be important as they can convey information about the startups underlying characteristics. These signals are a big issue in financing entrepreneurial projects and might be even more crucial in the context of equity crowdfunding as supporters from the crowd typically consist of less specialized investors having fewer value-relevant information about the targeted market [23] and are likely to be less experienced in the evaluation of investment opportunities [2]. Besides, having the focus on startup financing, where the underlying quality of the young enterprise cannot be observed directly, such quality signals appear to be of even higher importance compared to the financing of mature businesses. Also empirical findings on reward-based crowdfunding suggest that the success of an initiative is linked to the underlying project quality, where initiatives signaling a higher quality level are more likely to be funded [19]. In this crowdfunding service model, the asymmetry problems basically concern the entrepreneur's ability to deliver the product. In the equity setting a reinforcement 
of information asymmetries will arise because it likewise concerns an entrepreneur's ability to deliver the product, but also his capability to generate equity value with the business. Investors in equity crowdfunding are therefore exposed to an unusual high level of risk and are assumed to put an even higher focus on signals of quality. Within the contextual trait the dimensions funding status, founder's competence, frequent interaction, community effects and planning are captured as five potential signals of quality to investors.

Project Status. The project status includes both, the funding status as well as updates during an equity crowdfunding campaign. By analyzing the creditworthiness of borrowers in a microloan market, Zhang and Liu found strong support of herding behavior among lenders as funded borrowers tended to attract more funds and it is inferred that peer lender's decisions are observed by others and construed as a signal of a higher creditworthiness [26]. In a non-equity crowdfunding setting, Colombo et al. empirically showed that the capital raised in the early days of a campaign is a good predictor for an initiatives funding success [8]. Similar results come from Agrawal et al. who empirically showed that friends and family do invest early in an equity crowdfunding setting and concluded that these early contributions are likely to have a signal function to other investors which are, in addition, geographically more diffused [1]. Empirical evidence from an non-equity crowdfunding context suggest that an crowding-out effect might appear after the funding status comes close to the targeted amount as the allocated funds are construed as a sign of sufficient support that an initiative has received [6, 18]. For the equity crowdfunding models, an opposing effect is assumed as also investment behavior in traditional security markets is positively affected by increasing prior contributions. Also, qualitative and quantitative findings in the field of equity crowdfunding suggest that in a final stage of a funding round, where the collected funds are close to the aspired amount, the accumulated sum is again construed as a sign of quality and positively affects the funding success of an initiative $[1,13]$. Moreover, a study by Block et al. [4] empirically showed that updates since funding start such as new findings and business information about the development of the start-up can increase the likelihood of successful equity crowdfunding campaigns.

Founder's Competence. A founder's or the founding team's competence is captured as a signal for the trustworthiness of an entrepreneur that might be indicative of an advanced likelihood for a high quality project outcome. Based on a quantitative analysis among venture capitalists, Hsu has shown that prior founding experiences and founding teams with a doctoral degree holder receive higher firm valuations and are more likely to be funded via a direct venture capital tie [16]. By empirically investigating lending decisions in crowdfunding, Herzenstein et al. found that especially the number of identity claims of being trustworthy or successful do increase the individual likelihood of loan funding, whereas other types of claims, like moral and hardworking, do not have these effects [14]. The results show that social factors like a founder's credibleness play an important role in lending decisions. For equity crowdfunding, a case based analysis has shown that $89 \%$ of the investors agreed that the team appeared competent to them [23] and Ahlers et al. empirically showed that the entrepreneurs with a higher level of education are more likely to 
attract the crowd's support as this factors can be indicative of otherwise unobservable entrepreneurial activity [2].

Frequent Interaction. Ramkumar et al. empirically investigated the effects on costumers' social media participation and showed that high levels of activities and frequent information on social media platforms are positively associated with the customer's encouragement and consequently cause an increase in visits on those sides [22]. In a non-equity crowdfunding context, studies have outlined the importance of frequent communication that allow funders to articulate criticism and feedback [9, 19] but also for the equity crowdfunding setting it is suggested to encourage an active interaction with the crowd as investors want to support projects in which they can actively participate and provide a valuable contribution.

Community Effects. In a study on crowdfunding journalistic projects, Burtch et al. empirically examined the role of social influences and showed that the degree of support is positively associated with the stories' publication and concluded that the ability to increase the attention around a project, even for entrepreneurial ventures, is a chief benefit of the crowdfunding phenomenon [6]. Based on a quantitative analysis on reward-based crowdfunding, it has been furthermore emphasized that the number of Facebook friends similarly influences the crowdfunding success positively as they are the first community members around the project who spread the initial awareness [19]. In a case-based analysis on equity crowdfunding, Schwienbacher and Larralde found that the online community did increase the awareness of the initiative, but they simultaneously outlined the fact that the web community might likewise spread critical thoughts that affect the funding negatively [23]. So project backers might play a crucial role as their feedback, suggestions and comments might increase the visibility and be used by other investors to anticipate problems and opportunities and Hornuf et al. considers signaling to be one of the most important function in crowdfunding as a group of supporters is likely to be from the startups core market who can be easily mobilized as sales agents in their own social networks. It is therefore assumed that investors in equity crowdfunding infer a high quality project from a broad support and user generated content within the online community.

Planning. The last quality signal of the contextual trait is planning and refers to the business plan an entrepreneur reveals on the crowdfunding platform. The opportunity to participate with small amounts might be used as an argument against the importance of planning as small investments in crowdfunding do incorporate a lower risk compared to large amounts that are provided by venture capitalists or business angels. One might further argue that each minute spend on due diligence of the business plan for small amounts becomes relatively more expansive compared to additional efforts spend on analysis for large investment sums. However, by empirically analyzing signals in an equity crowdfunding setting, Ahlers et al. exposed the importance of financial roadmaps and projections. They showed that startups 
providing no financial forecasts at all do attract fewer investors and funds, revealing that the planning of an entrepreneur does have a positive signaling value to investors [2].

\subsection{Motivations of Supporters}

Collect Rewards. Within the motivational trait of collecting rewards a differentiation between extrinsic and intrinsic rewards is made as it is assumed that both dimensions jointly influence the intention regarding an activity as well as the actual behaviors of a person [7]. For the crowdsourcing environment, in which crowdfunding and also the equity service-models are rooted, participants are motivated by both, extrinsic and intrinsic rewards. On the one hand there are extrinsic rewards that guide a person's behavior towards an anticipated particular outcome, where the actual activity is performed because of goal-driven reasons to obtain some kind of external reward or benefits from a third part.

Selfish Reciprocity. The first dimension within the extrinsic rewards is selfish reciprocity and it is assumed that investors in equity crowdfunding can also be entrepreneurs at the same time. Reciprocity can be characterized as a tendency to return helpful acts in kind, dependent on the perceived intentions behind the action of others [20]. It is considered to be a vigorous parameter influencing human behavior and there is a strong evidence of reciprocal mechanisms in economic settings, which stands in contrast to the wide-spread assumption of purely self-interest behavior of economic actors [11]. For crowdfunding, motives of supporters are supposed to be consistent among all crowdfunding service models. However, people are motivated to fund others because they expect to attract them as funders for their own crowdfunding project in return. Later, in the motivational category of supporting others, a second reciprocal variable is formulated. For selfish reciprocity the funding is performed because of goal-driven reasons to obtain a benefit from a third party by attracting the funded person as a supporter for the own crowdfunding initiative in return.

Monetary Return. An anticipated monetary return is the second dimension within the extrinsic rewards as investors in crowdfunding may seek for financial gains with their participation. As also venture capitalists and business angels investment decisions are highly driven by financial objectives and as equity gains are the reward component that makes the equity-service model distinct from crowdfunding, they are assumably decisive. In a case-based study among investors in equity crowdfunding, Schwienbacher and Larralde found that for nearly $80 \%$ of the investors, economic profits were not a main motive for investing, while they at the same time did not want to make financial losses with their participation [23]. However, other qualitative findings among supporters in equity crowdfunding indicate that economic goals and the idea of realizing a monetary return are indeed the most important motives for participation [21]. 
Product Benefit. A personal benefit occurs if an investor personally profits from the product or service in a way that he experiences an increased utility [25]. In a crowdsourcing setting, the participation in virtual consumer integration for the development of new products is highly driven by the material outcome itself and less by the participation in the surrounding community. For equity crowdfunding models the mixture of pre-ordering and equity characteristics might indeed cause some form of synergy effects as it enables product enthusiasts to be early shareholders at the same time. This combination allows to align the incentives of consumers and product proponents with their means to enhance the value of the firm.

Curiosity. An intrinsic reward might be inherent in the phenomenon of crowdfunding itself and is directed to the dimension of interest driven behavior. For equity crowdfunding, Ordanini et al. qualitatively showed that funders are attracted by the novelty of crowdfunding itself, where the engagement in innovative behavior, the utilization of highly interactive tools and the new underlying technology are the driving motives for their participation [21]. Especially innovation oriented people might be attracted by the novelty of crowdfunding in a way that they are curious about the functionality and want to learn about it.

Hedonism. Another intrinsic reward is directed to the startup itself and has hedonic causes, referring to the intrinsic dimensions of enjoyment and pleasure. In a quantitative study among business angels financing new and early stage ventures, Sullivan and Miller (1996) classified three distinct types of investors, including financers whose participation is not just reasoned by monetary objectives but also influenced by hedonism. Also, research on equity crowdfunding indicates that fun and enjoyment can arise from the engagement in a project and from the feeling of being involved in the exciting adventure of building a project, as well as from observing the successful realization [23].

Support a venture. Literature on consumer behavior notes that specific investor types do assimilate personal core values into their regular investment decisions. However, it is more an alignment of dual goals as these investors are not willing to dismiss their financial objectives [17]. According to Gerber and Hui and Ordanini et al. the financial participation in a non-equity crowdfunding context is motivated by the benevolent intention to support the venture of an initiative and it is assumed that also investors in crowdfunding do not focus much on business plans and collaterals but rather appreciate the underlying ideas and core values of the enterprise $[13,21]$. Within this motivational trait, social utility and innovativeness are two distinct causes, which might increase a funder's propensity to invest.

Social Utility. A social utility arises if the successful realization of the startup is likely to enhance a societies overall welfare and studies in a non-equity crowdfunding context have identified social considerations as a crucial motive for participation [13]. Even though crowdfunding initiatives having a social meaning are often analyzed in a donation-based setting [23] it is suggested that firms with 
non-profit statuses are indeed the only organizational forms to attract donations sufficiently, a distinct focus on donation-based crowdfunding could leave out an important market alternative for the financing of early social ventures. Furthermore, considerable currents in the field of micro financing suggest that investors do contemplate the support of projects that incorporate a social meaning. A striking example that stresses the relevance of social investing is the lending-based crowdfunding platform Kiva.org, a non-profit intermediate where loans are granted to individuals or entrepreneurial groups without any interests being charged.

Innovativeness. In a case analysis on equity crowdfunding, Schwienbacher and Larralde found, that investors are interested in investing in new and innovative initiatives, rather than making financial profits and the supportiveness for innovative projects finds further support in a non-equity crowdfunding setting [23]. Also research on consumer behavior argues that the inherent tendency towards innovation of the consuming population caused the dynamic nature of our marketplace. The integration of a reward-based compensation might therefore reinforce the orientation towards innovation in the equity crowdfunding context as it attracts supporters.

Help others. According to qualitative studies, the intention to help other people is a crucial motive in a reward-based crowdfunding setting [12,15]. Also empirical findings on lending-based crowdfunding suggest that the nature of decision is both, financial and pro social as funders share characteristics with conventional financial decision making, but simultaneously purpose to help others with their investment, revealing the importance of supportiveness in a crowdfunding context [12]. In this motivational trait, a sense of identification with the founder, reciprocal behavior that is based on favorable intentions and altruistic tendencies are captured as motives that might induce potential investors to commit their financial resources.

Sense of Identification with Founder. A sense of identification with the founder or the founding team appears to be crucial determinants for investors in the equity crowdfunding setting [21]. The relationship between the funder and the entrepreneur can either be personal or extended and it is assumed that both forms can strengthen the identification with a crowdfunding initiator and consequently increase a potential funder's propensity to invest. A personal relationship encompasses the sphere of family and friend. For this direct relationship, Agrawal et al. empirically showed a positive effect for participation in an equity crowdfunding setting in the early stage of an initiatives financing round [1]. Also findings from qualitative interviews conducted by Gerber and Hui suggest that friend funding is an important factor and it is inferred that funding decisions are positively influenced on the recommendations of family and friends, which is considered to encompass the sphere of personal relationships [13]. Extended relationships might likewise cause some form of identification with the founder and can occur in various shapes as also weaker interpersonal ties like shared interests between two individuals are suggested to be decisive in a crowdfunding context [13]. 
Favorable Reciprocity. The exchange of a mutual "give and get" does not necessarily have to take place between two specific parties. Theory on indirect reciprocity suggests that people feel obliged to help others even if the previous helpful act was not directed to them but to others [20]. So a feeling of obligation towards a person may arise because the funder himself has received support from others beforehand and acts in a way to create a reciprocal balance in society. To recover, reciprocity is considered to be a vigorous parameter that has a great impact on many economic domains (Fehr and Gaechter 2000). By analyzing the role of social capital for early contributions in a reward-based crowdfunding setting, Colombo et al. found that social norms of reciprocal behavior have a significant influence on the funding success as founders who have supported crowdfunding initiatives of others beforehand did receive early capital and backers faster compared to those who did not support somebody else's project [8].

Altruism. Altruistic behavior is characterized as an unconditional kindness that is distinct from the conditional kindness motivated by reciprocity [6]. Altruistic support finds empirical evidence in a non-equity crowdfunding context [6]. Following the argument of Agrawal et al., it may also play a significant role in the equity setting as some investors even support commercial and profit orientated initiatives without receiving neither a tangible reward nor seeking to derive any other benefit from the participation in the surrounding online community [1].

Be part of a community. In this motivational trait, a social identification with a community and the pursuit of obtaining social recognition from a group of online peers are captured as possible motives for participation.

Social Identification. As outlined by the Social Identity Theory, individuals do show an inherent tendency to classify oneself, but also others, among different social categories. Qualitative findings indicate that next to the feeling of being obliged to help other individuals, supporters in reward-based crowdfunding do also show the desire to be part of a selected crowdfunding community of like-minded peers [13]. The authors conclude that the capability for group identification is a crucial characteristic of crowdfunding that satisfies the basic human need for belongingness. In a survey-based study on cognitive, affective and social determinants in open source communities, Bagozzi and Dholakia found that the effects of social identification and group membership are crucial motives for the member's participation [3]. Also Findings from a case-based analysis on equity crowdfunding indicate that supporters did participate in a closed online group around the project mainly due to personal relationships with other investors. Despite the fact that the group did provide the opportunity to create valuable business networks with other professionals, the active involvement was mainly reasoned by common passion and interest that the community members shared [23].

Social Recognition. The desire to obtain social recognition from a group of online peers is captured as the last potential motive for investors to support a startup through equity crowdfunding. Based on a quantitative analysis among members of an open 
source community, Bagozzi and Dholakia showed that next to social identification, the intention to obtain social status and group-based self-esteem are crucial determinants for the participation as well, acknowledging the social nature within these communities [3]. Also for the reward-based crowdfunding models, findings from a qualitative study point towards the fact that supporters desire to be recognized [13]. These characteristics find further support in a case-based analysis on equity crowdfunding which also suggests the desire for social recognition as a decisive motivation for an investor's involvement [23].

\section{Discussion}

In this paper we assess and evaluate quality signals for equity crowdfunding projects using online platforms. We systematically identified a collection of motivations, which may have positive impact on the potential investors' propensity to commit their financial resources. In our study the focus was laid on start-ups.

A number of supporters' motivations that may have an effect on the investment decision as well as non-motivational dimensions, referred to as contextual traits, are taken into account as they might convey information about the underlying and often not directly observable qualitative characteristics of the business. By providing different signals of quality, the contextual traits might consequently have an effect on an investor's decision for or against a financial participation equity crowdfunding platform project.

However, the investigation has several limitations that might be addressed in future research. As this paper discusses characteristics based on a qualitative analysis, future quantitative studies could be conducted to further analyze and reveal interdependencies or even statistical significance concerning these factors and characteristics.

As the literature analysis has mainly focused on characteristics concerning equity startup projects, future research could be dedicated to other relevant categories, like established companies or sector-specific enterprises.

Since crowdfunding activities may increase in terms of frequency and in terms of volume, this type of financing might have impact even on structural issues of financial markets and/or may lead to shifts in market forces. Although a tendency to regulate financial markets can be observed e.g. in Europe, equity crowdfunding represents a viable alternative or enrichment of traditional financial products. At the same time equity crowdfunding may be interpreted as a means of democratization and diversification in financial markets. The concept of a principal bank to name an example implies strong financial ties and dependencies as companies highly depend on their financial mainly institutionalized lenders. Many companies will prefer a diversification in this regard even if one lender wants to withdraw his/her investment, the other lenders will not necessarily follow. Many small investors imply increase independence and stability, and non-institutionalized investors imply more enthusiasm for investment especially into innovative and/or technology-driven business ideas. Operational overhead may use up some of the mentioned advantages. A research approach that develops an economic meta-view explores the question of the overall benefit of equity crowdfunding in terms of value creation for an economy rather than for specific players. 


\section{References}

1. Agrawal, A., Catalini, C., Goldfarb, A.: Offline relationships, distance, and the Internet: The geography of crowdfunding. Retrieved, 2 (2011)

2. Ahlers, G.K., Cumming, D., Günther, C., Schweizer, D.: Signaling in equity crowdfunding. Entrepreneurship Theory and Practice, Volume 39, No. 4, 955-980 (2015)

3. Bagozzi, R. P., Dholakia, U. M.: Open source software user communities: A study of participation in Linux user groups. Management science, 52(7), 1099-1115 (2006)

4. Block, J., Hornuf, L., \& Moritz, A.: Which updates during an equity crowdfunding campaign increase crowd participation?. Small Business Economics, 50(1), 3-27 (2018)

5. Bürger, B., Mladenow, A., Strauss, C.: Equity Crowdfunding Market: Assets and Drawbacks. Thirty eighth International Conference on Information Systems (ICIS), Special Interest Group on Big Data Processing. Seoul, 1-6 (2017)

6. Burtch, G., Ghose, A., Wattal, S.: An empirical examination of the antecedents and consequences of contribution patterns in crowd-funded markets. Information Systems Research, 24(3), 499-519 (2012)

7. Cholakova, M., Clarysse, B.: Does the possibility to make equity investments in crowdfunding projects crowd out reward-based investments?. Entrepreneurship Theory and Practice, 39(1), 145-172 (2015)

8. Colombo, M. G., Franzoni, C., Rossi-Lamastra, C.: Internal social capital and the attraction of early contributions in crowdfunding. Entrepreneurship Theory and Practice, 39(1), 75$100(2015)$

9. Drover, W., Busenitz, L., Matusik, S., Townsend, D., Anglin, A., Dushnitsky, G.: A review and road map of entrepreneurial equity financing research: Journal of Management, 43(6), 1820-1853 (2017)

10. Ernst, C., Mladenow, A., Strauss, C.: Collaboration and crowdsourcing in emergency management. International Journal of Pervasive Computing and Communications, 13(2), 176193 (2017)

11. Fehr, E., Gaechter, S.: Fairness and retaliation: The economics of reciprocity. The journal of economic perspectives, 14(3), 159-181 (2000)

12. Galak, J., Small, D., Stephen, A. T. (2011). Microfinance decision making: A field study of prosocial lending. Journal of Marketing Research, 48(SPL), S130-S137 (2011)

13. Gerber, E.M., Hui, J. (2013). Crowdfunding: Motivations and deterrents for participation. ACM Transactions on Computer-Human Interaction (TOCHI), 20(6) (2013)

14. Herzenstein, M., Sonenshein, S., Dholakia, U. M.: Tell me a good story and I may lend you money: the role of narratives in peer-to-peer lending decisions. Journal of Marketing Research, 48(Special Issue 2011), S138-S149 (2011)

15. Hornuf, L., Neuenkirch, M.:Pricing shares in equity crowdfunding. Small Business Economics 48(4),795-811 (2017)

16. Hsu, D. H.: Experienced entrepreneurial founders, organizational capital, and venture capital funding. Research Policy, 36(5), 722-741 (2007)

17. Iyer, E. S., Kashyap, R. K.: Noneconomic goals of investors. Journal of Consumer Behaviour, 8(5), 225-237 (2009)

18. Kuppuswamy, V., Bayus, B. L.: Crowdfunding creative ideas: The dynamics of project backers in Kickstarter. UNC Kenan-Flagler Research Paper, 2013-15 (2013)

19. Mollick, E.: The dynamics of crowdfunding: An exploratory study. Journal of business venturing, 29(1), 1-16 (2014)

20. Nowak, M. A., Sigmund, K.: Evolution of indirect reciprocity. Nature, 437(7063), 1291$1298(2005)$ 
21. Ordanini, A., Miceli, L., Pizzetti, M., Parasuraman, A.: Crowd-funding: transforming customers into investors through innovative service platforms. Journal of service management, Volume 22(4), 443-470 (2011)

22. Ramkumar, R., Kumar, A., Janakiraman, R., Bezawada, R.: The effect of customers' social media participation on customer visit frequency and profitability: an empirical investigation. Information systems research, 24(1), 108-127 (2013)

23. Schwienbacher, A., Larralde, B.: Crowdfunding of small entrepreneurial ventures. In: Cumming, D.J. (Ed.), The Oxford Handbook of Entrepreneurial Finance (2012)

24. Stuart, T. E., Hoang, H., Hybels, R. C.: Interorganizational endorsements and the performance of entrepreneurial ventures. Administrative science quarterly 44(2), 315- 349 (1999)

25. Vázquez, R., Del Rio, A. B., Iglesias, V.: Consumer-based brand equity: Development and validation of a measurement instrument. Journ. of Marketing Mgmt., 18(1-2), $27-48$ (2002)

26. Zhang, J., Liu, P.: Rational herding in microloan markets. Management science, 58(5), 892$912(2012)$ 